Krzysztof Prokop

\title{
Konstytucyjny system organów państwowych Republiki Litewskiej w pierwszych latach niepodległości (1918-1926)
}

Keywords: Lithuania, constitution, history

\section{Summary}

The purpose of the article is to present the constitutional development of the Republic of Lithuania after the First World War (1918-1926). This period may be divided into two parts: period of provisional constitutions (1918-1922) and period of the Constitution of Republic of Lithuania, which was enacted on August 1, 1922 and abolished in fact by a coup d'état in 1926. The parliamentary system of government was adopted by the first provisional constitution, which was enacted by the Taryba (Council of State) on November 2, 1918. The second provisional constitution was enacted on April 4, 1919. The institution of the President of the State was introduced by virtue of this constitution. The third provisional constitution was enacted by the Steigiamasis Seimas (Constituent Assembly) on June 10, 1920.

The Constitution of Republic of Lithuania adopted parliamentary system of government, which was known in provisional constitutions. The unicameral parliament (the Seimas) was the most important body of state authority. The President of the Republic was elected by the Seimas. He could be dismissed by the Seimas, too. The Cabinet of Ministers was appointed by the President. The Cabinet of Ministers had to get the vote of confidence from the Seimas. The Seimas could give the vote of no confidence, too. In this case the Cabinet of Ministers had to hand in its resignation. In practice the political scene was dominated by the Christian Democratic Party. It lost general election only in 1926. A coup d'état, which took place some months later, indicated the end of democratic system of government. 


\section{Uwagi wstępne}

Przedmiotem niniejszego opracowania jest ewolucja systemu konstytucyjnego Republiki Litewskiej w latach 1918-1926. W tym czasie na obszarze państwa litewskiego obowiązywały trzy konstytucje tymczasowe (z 1918, 1919 i 1920 r.) oraz Konstytucja Republiki Litewskiej z 1922 r. Nie jest możliwe rozpatrywanie systemu ustrojowego w konstytucji z 1922 r. bez uwzględnienia konstytucji tymczasowych. Przyjęto w nich rozwiązania, które następnie zaadaptowano we właściwej konstytucji. Chodzi tu przede wszystkim o zasadę preponderancji jednoizbowego parlamentu (Seimas), przy uwzględnieniu generalnej zasady trójpodziału władz. Można tu widzieć wpływ konstytucjonalizmu francuskiego, dominującego po I wojnie światowej w państwach Europy Środkowo-Wschodniej ${ }^{1}$, ale wyraźnie dostrzegalne są również rozwiązania weimarskie i szwajcarskie (zob. niżej, pkt 3.1). Przede wszystkim ten fakt odróżnia litewską konstytucję z 1922 r. od polskiej Konstytucji marcowej (1921). Wystąpiły w niej rozwiązania całkowicie obce ówczesnemu konstytucjonalizmowi w Polsce, takie jak instytucje demokracji bezpośredniej, czy odpowiedzialność polityczna prezydenta ${ }^{2}$. Należy również podkreślić bogate doświadczenia litewskie z konstytucjami tymczasowymi. Jak wspomniano, uchwalono ich aż trzy. Pierwsza obowiązywała pół roku, druga ponad rok, a trzecia prawie dwa lata. Ich charakterystyczną cechą było przejmowanie, częściowo dosłowne, przepisów z poprzednio obowiązujących konstytucji.

\section{System organów państwowych w okresie przejściowym (1918-1922)}

\subsection{Powstanie Republiki Litewskiej}

Podobnie jak w przypadku Polski pierwsze lata niepodległego państwa litewskiego naznaczone było prowizorium konstytucyjnym. Na Litwie trwało ono dłużej niż w Polsce (prawie cztery lata). Fakt ten należy tłumaczyć nie tylko sporem na temat kształtu ustroju państwa, ale też dramatycznymi okolicznościami towarzyszącymi powstaniu niepodległej Litwy.

Kształtowanie się litewskiej państwowości pod koniec I wojny światowej wiąże się przede wszystkim z działalnością Rady Państwa Litewskiego (Lietu-

1 Zob. J. Stembrowicz, Rzad w systemie parlamentarnym, Warszawa 1982, s. 84.

2 Wpływ polskiej konstytucji kwietniowej (1935) daje się natomiast dostrzec w Konstytucji Republiki Litewskiej z 1938 r.; zob. P. Kierończyk, Konstytucja kwietniowa i Konstytucja litewska z 1938 r. - próba porównania, [w:] Prawo konstytucyjne II Rzeczypospolitej. Nauka i instytucje. XLVII Ogólnopolski Zjazd Katedr i Zakładów Prawa Konstytucyjnego, red. P. Sarnecki, Kraków 2006, s. 240-251. 
vos Valstybés Taryba, dalej jako Taryba ${ }^{3}$ ). Powołana pod auspicjami władz niemieckich we wrześniu 1917 r. ${ }^{4}$ stała się reprezentantką środowisk niepodległościowych ${ }^{5}$. Taryba była pierwotnie tylko organem doradczym, reprezentującym ludność przy władzach niemieckich, z ograniczonymi kompetencjami ${ }^{6}$. Jej najważniejszym aktem było uchwalenie dwóch deklaracji niepodległości. Pierwsza, z 11 grudnia 1917 r., przewidywała utworzenie związku państwowego z Niemcami. Druga, z 16 lutego 1918 r., zakładała już powołanie niezależnego państwa ${ }^{7}$. W ramach ustępstw w stosunku do władz niemieckich Litwini zgodzili się na utworzenie królestwa, którego władcą miał zostać książę Wilhelm Urach wittemberski jako Mendog $\mathrm{II}^{8}$. W planach władz niemieckich Litwa miała być państwem buforowym, oddzielającym Niemcy od Rosji ${ }^{9}$. Wszystkie te kalkulacje straciły na aktualności w związku z klęską państw centralnych w I wojnie światowej. Taryba ogłosiła się najwyższą władzą, zerwała związki z Niemcami i powołała rząd ${ }^{10}$.

\subsection{Pierwsza tymczasowa konstytucja}

2 listopada 1918 r. Taryba uchwaliła pierwszą tymczasową konstytucję niepodległej Litwy ${ }^{11}$. W świetle pkt. 1 konstytucji ${ }^{12}$ organami władzy państwowej

3 Początkowo organ ten nosił nazwę Litewska Rada Krajowa (Lietuvos Krašto Taryba); nową nazwę przyjęto w dniu 11 lipca 1918 r. Zob. H. Wisner, Litwa. Dzieje państwa i narodu, Warszawa 1999, s. 164; J. Ochmański, Historia Litwy, Wrocław-Warszawa-Kraków 1990, s. 271.

4 Zob. J. Ochmański, Historia..., s. 267. Jak wskazuje P. Łossowski, „Niemcy traktowali Tarybę instrumentalnie, wykorzystując fakt jej istnienia na arenie międzynarodowej” (P. Łossowski, Państwo litewskie 1918-1940. Kierunki rozwoju, „Obóz” 1992, nr 22, s. 80).

5 Udziału w Tarybie odmówiła polska mniejszość narodowa, licząca na odtworzenie przedrozbiorowej Rzeczypospolitej. Inaczej postąpiła mniejszość żydowska i białoruska. Ich przedstawiciele z czasem uzyskali reprezentację w Tarybie i rządzie litewskim (zob. niżej, pkt 2.2).

6 P. Klimas, Der Werdegang des Litauischen Staates von 1915 bis zur Bildung der provisorischen Regierung im November 1918, Berlin 1919, s. XV.

P. Kierończyk, Państwo bez parlamentu. Kilka uwag do międzywojennej historii konstytucjonalizmu litewskiego, „Przegląd Sejmowy” 2003, nr 4, s. 81 i przypis 2 na tejże stronie.

8 J. Ochmański, Historia..., s. 271.

9 J. Zieliński, Instytucjonalizacja przemian ustrojowych na Litwie, Łotwie i w Estonii, Warszawa 2004, s. 19 , przypis 8 .

${ }^{10}$ D. Świgliński, Litwa, [w:] Nowa dziesiątka Unii Europejskiej, red. D. Jędrzejczyk, Warszawa 2005, s. 206.

${ }^{11}$ Konstytucja nosiła oficjalną nazwę: Podstawy tymczasowej konstytucji Państwa Litewskiego. Konstytucja została ogłoszona najpierw w „Lietuvos aidas” nr 130 (178) z 13 listopada 1918 r., zaś później w „Laikinosis Vyriausybès Žinių Papildymas”, nr 1. W niniejszym opracowaniu wykorzystano niemieckie tłumaczenie konstytucji [w:] P. Klimas, Der Werdegang..., op. cit., s. 213-215. Tymczasowy charakter konstytucji wynikał bezpośrednio z samego tytułu konstytucji, jak również z postanowień preambuły. Konstytucja miała obowiązywać do czasu nadania formy rządów i konstytucji przez Sejm Ustawodawczy. W praktyce utraciła moc obowiązującą wraz z uchwaleniem drugiej tymczasowej konstytucji.

${ }^{12}$ Konstytucja nie używała podziału na artykuły. Istnieją pod tym względem pewne podobieństwa z polską Małą konstytucją (1919). Por. uwagi P. Kierończyka, System konstytucyjny państwa litewskiego (1922-1940), Gdańsk 2008, s. 32, przypis 55. 
były: Rada Państwa (Valstybés Taryba), Prezydium Rady Państwa (Taryby) i Gabinet Ministrów. Mimo tymczasowego charakteru konstytucja wywarła znaczący wpływ na kształt późniejszej konstytucji z 1922 r.

Taryba miała pełnić funkcje parlamentu do czasu zwołania Sejmu Ustawodawczego. $Z$ tego też powodu nie podlegała rozwiązaniu. Prezydium zwoływało sesje Taryby $\mathrm{z}$ inicjatywy własnej lub na wniosek $1 / 3$ członków Taryby (pkt 8). Taryba pełniła funkcję ustrojodawczą, ustawodawczą i kontrolną. Była ciałem wykonującym najwyższą władzę państwową (suprema potestas). Zmieniała konstytucję większością 2/3 głosów na wniosek połowy jej członków (pkt 4). Głównym zadaniem Taryby było uchwalanie ustaw. Inicjatywa ustawodawcza przysługiwała Tarybie i Gabinetowi Ministrów (pkt 3). Taryba pełniła również funkcję kontrolną wobec rządu. Miała prawo składania interpelacji i zapytań (pkt 7). Ministrowie byli obowiązani udzielać odpowiedzi i wyjaśnień na żądanie Taryby i jej komisji (pkt 21). Ponadto Taryba ratyfikowała umowy międzynarodowe (pkt 5).

Prezydium Taryby (Valstybés Tarybo Prezidiumas) pełniło funkcję kolegialnej głowy państwa. Składało się z przewodniczącego i dwóch wiceprzewodniczących powoływanych przez Tarybę. Prezydium powoływało premiera i powierzało mu misję stworzenia rządu (pkt 11 lit. b), reprezentowało państwo (pkt 11 lit. c), powoływało ambasadorów i przyjmowało listy uwierzytelniające od przedstawicieli innych państw (pkt 11 lit. d), powoływało wyższych urzędników cywilnych i wojskowych (pkt 11 lit. e), sprawowało pieczę nad ochroną niepodległości Litwy i jej terytorialnej integralności, sprawowało naczelne dowództwo i powoływało naczelnego wodza (pkt 11 lit. f). Akty Prezydium wymagały podpisu wszystkich trzech jego członków (pkt 13) i były kontrasygnowane przez premiera i ministra (pkt 12). Gabinet Ministrów ponosił solidarną odpowiedzialność za akty Prezydium wobec Taryby. Formalnie Prezydium nie ponosiło przed Tarybą odpowiedzialności politycznej. Jednakże - obok pełnienia funkcji głowy państwa - było również organem wewnętrznym Taryby, wobec tego mogła ona zmieniać jego skład ${ }^{13}$. Pierwszym przewodniczącym Prezydium został Antanas Smetona, przedstawiciel partii narodowców (tautininków) ${ }^{14}$.

Gabinet Ministrów (Ministeriu Kabinetas) składał się z premiera i ministrów. Gabinet Ministrów był powoływany przez Prezydium (pkt 15 i 16). Można było łączyć mandat parlamentarny z członkostwem w Gabinecie Ministrów (pkt 20). Gabinet Ministrów był ciałem kolegialnym i ponosił odpowiedzialność solidarną (pkt 17). Taryba mogła uchwalić wotum nieufności wobec całego Gabinetu ${ }^{15}$,

${ }^{13}$ M. Römer, Organizacja władzy politycznej w rozwoju konstytucyjnym Republiki Litewskiej, „Wydawnictwa Grup Polskich Porozumień Prawniczych z Zagranicą” 1939, z. 4, s. 47.

${ }^{14}$ A. Smetona stał na czele Prezydium Taryby od września 1917 r. (zob. H. Wisner, Litwa..., s. 161). Wówczas jednak Prezydium było wyłącznie organem wewnętrznym Taryby.

${ }^{15}$ M. Römer, Organizacja..., s. 47. 
jak i wobec poszczególnych ministrów. Jeżeli Taryba uchwaliła wotum nieufności wobec jednego ministra, ustępował cały Gabinet (pkt 18).

Konstytucja z 2 listopada 1918 r. (podobnie jak późniejsze konstytucje tymczasowe) nie regulowała władzy sądowniczej. Uczyniła to Taryba w akcie z 28 listopada 1918 r. Sądami najniższej instancji były sądy pokoju, które tworzyli pojedynczy sędziowie. Drugą instancję tworzyły sądy okręgowe z siedzibami w Kownie, Mariampolu, Poniewieżu i Szawlach. Na czele hierarchii sądów powszechnych stał Najwyższy Trybunał Litewski. W późniejszych latach nie nastąpiły zasadnicze zmiany w strukturze sądownictwa, aż do 1934 r., gdy powołano Sąd Apelacyjny, a sądy pokoju zastąpiono sądami powiatowymi ${ }^{16}$.

Pierwszym premierem został Augustinas Voldemaras (11 listopada 1918 r.), który pełnił również funkcję ministra spraw zagranicznych. Gabinet A. Voldemarasa był rządem technokratycznym, nie opierał się na większości parlamentarnej. Niemniej jego ostateczny skład należy uznać za sukces Partii Postępu Narodowego (tautininków), która zdominowała Tarybę. Reprezentację w gabinecie A. Voldemarasa uzyskali przedstawiciele mniejszości żydowskiej i białoruskiej ${ }^{17}$.

W grudniu 1918 r. bolszewicy zainstalowali na Litwie Tymczasowy Rewolucyjny Rząd Robotniczo-Włościański Vincasa Mickievičiusa-Kapsukasa ${ }^{18}$. Wraz z zajęciem Wilna przez wojska radzieckie gabinet ten uznano za rząd Republiki Litewsko-Białoruskiej ${ }^{19}$. Cały czas jednak w Kownie funkcjonowała Taryba ${ }^{20}$. W czasie najazdu Armii Czerwonej nastąpiła zmiana na stanowisku premiera. A. Voldemarasa, który znalazł się za granicą, zastąpił Mykolas Slezevičius (26 grudnia 1918 r. $)^{21}$. Wilno na kilka dni dostało się w ręce polskie, ale już 5 stycznia 1919 r. miasto zajęli bolszewicy. Rząd M. Slezevičiusa ewakuował się do Kowna. Władzę radziecką obaliło wejście wojsk polskich w kwietniu 1919 r. Wileńszczyzna dostała się w ręce Polaków, a stolicą władz litewskich pozostało Kowno ${ }^{22}$.

Toczące się na obszarze państwa działania zbrojne zmusiły Litwinów do wzmocnienia egzekutywy. Na podstawie noweli konstytucyjnej z 24 stycznia 1919 r. ${ }^{23}$ rząd otrzymał prawo wydawania ustaw tymczasowych w czasie przerwy

${ }^{16}$ H. Wisner, Litwa..., s. 189. Ustrój sądownictwa litewskiego po zmianach wprowadzonych w $1934 \mathrm{r}$. omawia S. Płaza, Historia prawa w Polsce na tle porównawczym, cz. 3: Okres międzywojenny, Kraków 2001, s. 640.

${ }^{17}$ Sześciu Białorusinów i trzech Żydów zasiadło również w Tarybie (A. E. Senn, The Emergence of Modern Lithuania, New York 1959, s. 49).

${ }^{18}$ J. Ochmański, Historia..., s. 278.

${ }^{19}$ Ibidem, s. 280.

${ }^{20} \mathrm{~J}$. Zieliński, Instytucjonalizacja..., s. 21.

${ }^{21}$ M. Slezevičiusowi zaproponowano objęcie dyktatury, ale ten odmówił; zob. P. Łossowski, Litwa, Warszawa 2001, s. 72-73; H. Wisner, Litwa..., s. 168.

${ }^{22}$ J. Zieliński, Rząd Republiki Litewskiej, [w:] E. Zieliński, J. Zieliński, Rzady w państwach Europy, t. 3, Warszawa 2006, s. 121.

${ }^{23}$ „Laikinosis Vyriausybès Žinios” nr 4. 
między sesjami Taryby. Podlegały one rozpatrzeniu przez Tarybę na najbliższej sesji ${ }^{24}$. Złagodzono również bezwzględny wymóg kolegialności w pracach Prezydium. Zmiana była spowodowana faktem, że nie zawsze wszyscy trzej członkowie Prezydium przebywali w jednym miejscu. W razie potrzeby wystarczał podpis tylko jednego członka. Jednakże przy obecności dwóch lub trzech członków w jednym miejscu wymagano ich podpisów pod uchwałą Prezydium ${ }^{25}$.

\subsection{Druga tymczasowa konstytucja}

Konstytucja z 2 listopada 1918 r. miała obowiązywać do czasu uchwalenia nowej konstytucji przez Sejm, niemniej obowiązywała tylko pół roku. Druga tymczasowa konstytucja niepodległej Litwy została uchwalona przez Tarybę 4 kwietnia 1919 r. ${ }^{26}$ Konstytucja prowadziła do dalszego umacniania władzy wykonawczej. Tendencja ta ujawniła się już przy nowelizacji z 24 stycznia 1919 r. i wynikała z trudnej sytuacji politycznej Litwy, a zwłaszcza toczących się działań zbrojnych. Najważniejszą zmianą było powołanie instytucji Prezydenta Państwa. Prezydium pozostało organem wewnętrznym Taryby ${ }^{27}$. Pozycja ustrojowa Taryby i Gabinetu Ministrów nie uległa większym zmianom. Taryba nadal pełniła funkcję ustrojodawczą, ustawodawczą i kontrolną na podobnych zasadach jak w konstytucji z 1918 r. Niemniej nastąpiło dość poważne osłabienie jej pozycji na rzecz prezydenta i rządu.

Dla nowej głowy państwa przyjęto tytuł „Prezydent Państwa”, a nie „Prezydent Republiki”, gdyż o formie państwa miał zadecydować dopiero Sejm Ustawodawczy ${ }^{28}$. Do momentu ukonstytuowania się Sejmu Ustawodawczego i ustanowienia organizacji państwa, prezydenta wybierała Taryba $(\$ 6)$. Nie określono kadencji prezydenta, miał urzędować do końca prowizorium konstytucyjnego. Prezydent nie ponosił odpowiedzialności przed Tarybą. Nie można było usunąć go przed upływem kadencji ${ }^{29}$. W razie śmierci prezydenta lub tymczasowej niemożności pełnienia przez niego urzędu, jego obowiązki sprawował przewodniczący Taryby $(\$ 7)$. Prezydent należał do organów władzy wykonawczej, którą sprawował przez Gabinet Ministrów $(\$ 8)$. Prezydent - na podstawie $\$ 17$ - dysponował słabym wetem ustawodawczym wobec ustawy uchwalonej przez Ta-

${ }^{24}$ P. Kierończyk, System..., s. 34, przypis 63.

${ }^{25}$ P. Klimas, Der Werdegang..., przypis na s. 214.

${ }^{26}$ Konstytucja z 1919 r. nosiła oficjalny tytuł: „Zasady Podstawowe Tymczasowej Konstytucji Państwa Litewskiego". Niemieckie tłumaczenie konstytucji [w:] A. Hollstein, Das staatsorganisatorische Modell der neuen litauischen Verfassung. Ein dritter Weg zwischen präsidialem und parlamentarischem System?, Köln 1999, s. 151-156.

${ }^{27}$ J. Zieliński, Instytucjonalizacja..., s. 20.

28 Praktycznie decyzja o odrzuceniu monarchicznej formy państwa zapadła już w listopadzie 1918 r. (J. Ochmański, Historia..., s. 272).

${ }^{29}$ M. Römer, Organizacja..., s. 48. 
rybę. Ustawa musiała być rozpatrzona po raz drugi i ponownie przyjęta zwykłą większością głosów ${ }^{30}$. Prezydent nie mógł rozwiązać Taryby.

W okresie między sesjami Taryby Prezydent miał prawo do wydawania ustaw. Faktycznie ich autorem był Gabinet Ministrów, który najpierw przyjmował odpowiedni projekt. Prezydent mógł wobec niego złożyć weto. Jeżeli Gabinet podtrzymał swój projekt, prezydent go promulgował jako ustawę albo ponawiał weto. $\mathrm{W}$ tej drugiej sytuacji następowało automatyczne wznowienie sesji Taryby, która przyjmowała bądź odrzucała projekt Gabinetu ${ }^{31}$. Ustawy wydane przez prezydenta na wniosek Gabinetu Ministrów nie podlegały rozpatrzeniu przez Tarybę $(\$ 16)^{32}$. Niewątpliwie uprawnienie do wydawania ustaw w zastępstwie Taryby najbardziej umacniało pozycję ustrojową prezydenta kosztem Taryby. Nie bez znaczenia było również zastąpienie przez prezydenta kolegialnego ciała, jakim było Prezydium ${ }^{33}$. Oprócz prawa do zastępczego wydawania ustaw prezydent przejął kompetencje Prezydium wykonywane w charakterze głowy państwa $^{34}$. Akty prezydenta podlegały ministerialnej kontrasygnacie.

Na pierwszego prezydenta Taryba wybrała A. Smetonę. Jego pozycja była silna. Z racji na konflikt między Tarybą a Gabinetem Ministrów wydawał ustawy na zasadach omówionych powyżej. Łączył w ten sposób władzę ustawodawczą i wykonawczą ${ }^{35}$. Pomyślnie układała się współpraca prezydenta z premierem M. Slezevičiusem. Nie zwoływano natomiast posiedzeń Taryby, co stało się bezpośrednią przyczyną upadku gabinetu M. Slezevičiusa w październiku 1919 r. Nowym premierem został Ernestas Galvanauskas ${ }^{36}$.

\subsection{Trzecia tymczasowa konstytucja}

Stabilizacja sytuacji wewnętrznej w $1919 \mathrm{r}^{37}$ umożliwiła przygotowanie i przeprowadzenie wyborów do Sejmu Ustawodawczego (Steigiamasis Seimas).

${ }^{30}$ A. Hollstein, Das staatsorganisatorische Modell..., s. 35.

${ }^{31}$ Należy dodać, że Gabinet Ministrów posiadał inicjatywę ustawodawczą, dzięki której mógł doprowadzić do uchwalenia ustawy przez Tarybę.

${ }^{32}$ Możliwość zastępczego wydawania ustaw przez głowę państwa przejęto z dawnego systemu konstytucyjnego Rosji (A. Hollstein, Das staatsorganisatorische Modell..., s. 35; J. Robinson, Der litauische Staat und seine Verfassungsentwicklung, „Jahrbuch des öffentlichen Rechts“ 1928, Band 16, s. 303). Jednakże w carskiej Rosji ustawę wydaną przez cara w okresie przerwy między pracami parlamentu przedstawiano do zatwierdzenia obu izbom (Dumie Państwowej i Radzie Państwa) w okresie dwóch miesięcy od wznowienia prac parlamentu, pod rygorem utraty mocy obowiązującej (A. Nowakowski, Historia ustroju państw w zarysie, Białystok 1993, s. 181).

${ }^{33}$ A. Hollstein, Das staatsorganisatorische Modell..., s. 35.

${ }^{34}$ Nowością było powoływanie przez prezydenta kontrolera państwowego (\$39).

${ }^{35}$ A. Hollstein, Das staatsorganisatorische Modell..., s. 35.

${ }^{36}$ P. Łossowski, Litwa..., s. 81.

${ }^{37}$ Jej przejawem było zwłaszcza uporanie się z oddziałami tzw. bermontczyków; zob. J. Ochmański, Historia..., s. 283; J. Żenkiewicz, Litwa na przestrzeni wieków i jej powiązania z Polską, Toruń 2001, s. 146; Z. Kiaupa, The History of Lithuania, Vilnius 2002, s. 329-330; P. Kierończyk, System..., s. 35, przypis 65. 
Wybory odbyły się 14 i 15 kwietnia 1920 r. na podstawie $\$ 31$ konstytucji z 1919 r., który przewidywał oparcie prawa wyborczego na zasadach powszechności, równości, bezpośredniości i głosowania tajnego. Frekwencja wyniosła w granicach $85-92 \%{ }^{38}$. Wybory wygrała Partia Chrześcijańsko-Demokratyczna, zdobywając większość bezwzględną (59 mandatów) ${ }^{39}$. Na czele koalicyjnego rządu stanął ludowiec - Kazys Grinius, ale chadecja wywierała decydujący i z biegiem czasu coraz większy wpływ na politykę gabinetu ${ }^{40}$. Sejm Ustawodawczy zebrał się na pierwsze posiedzenie 15 maja 1920 r. i ponowił proklamację niepodległości ${ }^{41}$.

Trzecią tymczasową konstytucję Sejm Ustawodawczy uchwalił 10 czerwca 1920 r. $^{42}$ Konstytucja składała się z siedmiu rozdziałów i osiemnastu paragrafów. Litwa została określona jako republika demokratyczna $(\$ 1)^{43}$. Konstytucja wprowadziła system władzy opartej na zasadzie nadrzędności parlamentu ${ }^{44}$. Sejm Ustawodawczy był wyrazicielem władzy suwerennej narodu $(\$ 2)$, pełniąc podobnie jak poprzednio Taryba - funkcję ustrojodawczą, ustawodawczą i kontrolną. Sejm uchwalał ustawy, ratyfikował umowy międzynarodowe, zatwierdzał budżet i kontrolował wykonywanie ustaw $(\$ 4)$. Inicjatywa ustawodawcza przysługiwała Sejmowi Ustawodawczemu i Gabinetowi Ministrów (\$6).

Władzę wykonawczą tworzył Prezydent Republiki i Gabinet Ministrów $(\$ 5)$. Podobnie jak poprzednio, prezydent nie miał stałej kadencji. Czas jego urzędowania był równoznaczny z końcem prowizorium konstytucyjnego. W porównaniu do tymczasowej konstytucji z 1919 r. jego pozycja była słaba, sprowadzała się do pełnienia funkcji reprezentacyjnych. Prezydent utracił uprawnienie do wetowania ustaw, wydawania ustaw $\mathrm{w}$ zastępstwie parlamentu i sprawowania naczelnego dowództwa. Prezydent powoływał premiera, powierzał mu misję sformowania rządu, zatwierdzał skład Gabinetu i przyjmował jego dymisję ( $\$ 8$ lit. a), powoływał kontrolera państwowego $(\$ 8 \text { lit. b })^{45}$, reprezentował Republikę ( $\$ 8$ lit. c), powoływał ambasadorów i przyjmował listy uwierzytelniające od przedstawicieli państw obcych ( $\$ 8$ lit. d), powoływał wyższych funkcjona-

${ }^{38}$ A. Hollstein, Das staatsorganisatorische Modell..., s. 36, przypis 126; zob. M. Römer, Die Verfassungsreform Litauens vom Jahre 1928, München 1930, s. 53.

${ }_{39}$ Do Sejmu weszło również dwudziestu przedstawicieli Związku Chłopskiego, trzynastu socjaldemokratów, dziewięciu ludowców i dziesięciu przedstawicieli mniejszości narodowych (w tym trzech Polaków). Żadnego mandatu nie dostała Partia Postępu Narodowego prezydenta A. Smetony; zob. D. Świgliński, Litwa..., s. 206.

${ }^{40}$ P. Łossowski, Kraje battyckie na drodze od demokracji parlamentarnej do dyktatury (1918-1934), Wrocław-Warszawa-Kraków-Gdańsk 1972, s. 21.

${ }^{41}$ Tekst deklaracji [w:] A. E. Senn, The Emergence..., s. 216.

${ }^{42}$ „Laikinosis Vyriausybės Žinios” nr 37 z 12 czerwca 1920 r. Niemieckie tłumaczenie [w:] A. Hollstein, Das staatsorganisatorische Modell..., s. 157-159.

${ }^{43}$ W konstytucji z 1920 r. ostatecznie przesądzono o republikańskiej formie państwa.

${ }^{44}$ M. Römer, Organizacja..., s. 49.

${ }^{45}$ Kontroler państwowy ponosił odpowiedzialność przed Sejmem i ustępował w razie udzielenia mu wotum nieufności $(\$ 14)$. 
riuszy cywilnych i wojskowych ( $\$ 8$ lit. e), ogłaszał ustawy ( $\$ 8$ lit. f) i stosował prawo łaski ( $\$ 8$ lit. g). Wszystkie akty prezydenta wymagały kontrasygnaty premiera lub ministra. Gabinet Ministrów był ciałem kolegialnym i ponosił odpowiedzialność solidarną ( $\$ 11)$. Ustępował w razie wyrażenia przez Sejm wotum nieufności $(\$ 12)$.

W świetle $\$ 9$ funkcje prezydenta, do czasu jego wyboru, miał pełnić przejściowo przewodniczący parlamentu. W praktyce Sejm nie dokonał elekcji nowej głowy państwa. W ten sposób jej obowiązki pełnił przewodniczący Sejmu, Aleksandras Stulginskis z chrześcijańskiej demokracji. Urząd głowy państwa utracił A. Smetona, którego partia - jak wspomniano wyżej - nie zdobyła ani jednego mandatu w wyborach do Sejmu Ustawodawczego. Praktyka ustrojowa odpowiadała w zasadzie literze konstytucji. A. Stulginskis pełnił funkcje reprezentacyjne. Ciężar rządów spoczywał na Gabinecie Ministrów i Sejmie Ustawodawczym, w którym dominowali chrześcijańscy demokraci.

Z ciekawym eksperymentem ustrojowym mieli do czynienia Litwini w okresie zamachu Żeligowskiego. Z powodu wybuchu działań zbrojnych Sejm zawiesił swoją działalność, ale nie upoważnił rządu do zastępczego wydawania ustaw (względnie dekretów z mocą ustawy). Zamiast tego wyłonił ze swojego grona komitet zastępczy - tzw. Mały Sejm. Jego istnienia nie przewidywały przepisy konstytucyjne. Mały Sejm sprawował funkcję ustawodawczą i kontrolną. W skład Małego Sejmu wchodził przewodniczący Sejmu (jak wiadomo A. Stulginskis pełnił również funkcję prezydenta) oraz sześciu członków wybranych przez Sejm ${ }^{46}$.

\section{System organów władzy państwowej w konstytucji z 1922 r.}

\subsection{Ogólna charakterystyka}

Projekt konstytucji Republiki Litewskiej przygotowała komisja konstytucyjna Sejmu Ustawodawczego, zdominowana przez rządzących chadeków ${ }^{47}$. W pracach konstytucyjnych wykorzystano popularny wówczas model francuskiego systemu parlamentarnego. Niemniej w konstytucji litewskiej z 1922 r. dają się dostrzec wzorce zaczerpnięte także z innych państw, zwłaszcza z Republiki Weimarskiej, a nawet ze Szwajcarii ${ }^{48}$. Sejm uchwalił Konstytucję Republiki

${ }^{46}$ M. Römer, Organizacja..., s. 50; P. Kierończyk, System..., s. 37, przypis 75; H. Wisner, Litwa..., s. 190-191; A. B. Zakrzewski, Wstęp, [w:] Konstytucja Republiki Litewskiej, Warszawa 2006, s. 12; A. Bobrus, Doświadczenia i dorobek litewskiego konstytucjonalizmu, [w:] Prawo. Administracja. Obywatele. Profesorowi Eugeniuszowi Smoktunowiczowi, red. A. Jamróz, Białystok 1997, s. 42-43.

${ }^{47}$ Zob. P. Kierończyk, System..., s. 39. Socjaldemokratyczny poseł Kipras Bielnis stwierdził: „Mówimy teraz i powtarzać będziemy w przyszłości, że ta konstytucja jest tylko waszą, bloku chrześcijańsko-demokratycznego, konstytucją" (P. Łossowski, Litwa..., s. 99).

${ }^{48}$ Wpływy konstytucjonalizmu weimarskiego i szwajcarskiego widoczne były we wszystkich państwach bałtyckich. Wzorce weimarskie występowały zwłaszcza na Litwie i Łotwie, zaś w Estonii do- 
Litewskiej (Lietuvos Valstybés Konstitucija) 1 sierpnia 1922 r. ${ }^{49}$. Weszła w życie z dniem ogłoszenia, czyli 6 sierpnia 1922 r. Składała się z 15 rozdziałów i 108 paragrafów, poprzedzonych wstępem. Uchwalenie konstytucji zakończyło proces formowania się podstaw ustrojowych niepodległej Litwy ${ }^{50}$.

Treść konstytucji z 1922 r. przypomina $\mathrm{w}$ dużym stopniu postanowienia konstytucji tymczasowych. Przyjęto w niej zasadę republikańskiej formy państwa i zasadę zwierzchnictwa narodu $(\$ 1)$. Cechą wszystkich konstytucji państw bałtyckich uchwalonych bezpośrednio po I wojnie światowej jest podkreślenie idei suwerenności narodu. Konsekwencją tego założenia było umocnienie pozycji parlamentu (kosztem władzy wykonawczej). Mechanizmy demokracji przedstawicielskiej uzupełniono o instytucje demokracji bezpośredniej ${ }^{51}$. Konstytucja nie deklarowała wprost oparcia systemu organów państwowych na zasadzie trójpodziału władz. W świetle $\$ 2$ władzę państwową wykonywał Sejm, Rząd ${ }^{52}$ i Sąd. Należy jednak uznać, że zasada trójpodziału władz - mimo dominującej pozycji Sejmu - została zachowana, zważywszy na całość relacji między konstytucyjnymi organami państwa.

\section{2. Sejm}

\subsubsection{Organizacja i tryb funkcjonowania Sejmu}

Jednoizbowy Sejm ${ }^{53}$ składał się z 78 posłó $w^{54}$ wybieranych na trzyletnią kadencję $(\$ 25)^{55}$. Liczbę deputowanych określała ustawa ( $\$ 23$ konstytucji) na zasadzie stałej normy przedstawicielstwa. Jeden mandat przypadał na 25000 mieszkańcó $w^{56}$. Posłowie do Sejmu byli wybierani w drodze wyborów powszechnych, bezpośrednich, równych, proporcjonalnych, w głosowaniu tajnym $(\$ 23)$. Czynne prawo wyborcze przysługiwało obywatelom (mężczyznom i kobietom) po ukończeniu 21 roku życia, bierne zaś po ukończeniu 24 lat $(\$ 24)$. Wybory

minowały rozwiązania szwajcarskie. Na prace konstytucyjne wywarły wpływ doświadczenia również innych państw, m.in. Belgii, Czechosłowacji i Finlandii. Zob. P. Łossowski, Kraje battyckie.., s. 22-23; P. Kierończyk, System..., s. 38-39, przypis 78; A. B. Zakrzewski, Wstęp..., s. 12 i przypis 18 na tejże stronie; J. Zieliński, Instytucjonalizacja..., s. 24; P. Łossowski, Litwa..., s. 97-98.

${ }_{49}$ „Vyriausybès Žinios”, nr 100, z 6 sierpnia 1922 r. Polskie tłumaczenie: Nowe konstytucje, red. J. Makowski, Warszawa 1925, s. 155-177.

${ }^{50}$ J. Zieliński, Rząd..., s. 122.

${ }^{51}$ P. Kierończyk, Kilka uwag o genezie i specyfice konstytucji łotewskiej, „Gdańskie Studia Prawnicze" 2005, t. XIV, s. 280-281.

${ }^{52}$ Pod pojęciem „Rządu” konstytucja rozumiała Prezydenta Republiki i Gabinet Ministrów ( $\left.\$ 40\right)$.

${ }^{53}$ Warto odnotować, że w pracach konstytucyjnych pojawiły się głosy o potrzebie wprowadzenia bikameralizmu; zob. A. Hollstein, Das staatsorganisatorische Modell..., s. 39-40 i tam cytowana literatura.

${ }^{54}$ Konstytucja określała również posłów mianem „przedstawicieli narodu”.

${ }^{55}$ Krótka, bo zaledwie trzyletnia, kadencja Sejmu była wówczas normą w państwach bałtyckich, przewidywały ją również konstytucje Estonii (\$ 39) i Łotwy (art. X).

${ }^{56}$ W skład Sejmu III kadencji, wybranego w dniach 8-10 maja 1926 r., wchodziło 85 posłów. Zwiększenie liczby deputowanych miało związek z przyłączeniem regionu Kłajpedy (P. Kierończyk, Litewskie konstytucje z okresu międzywojennego, „Gdańskie Studia Prawnicze” 2000, t. VII, s. 247, przypis 18). 
musiały się odbyć przed upływem kadencji starego Sejmu w dniu wyznaczonym przez prezydenta. Pierwsze posiedzenie Sejmu zwoływał prezydent nie później niż 30 dnia od zakończenia wyborów. Kadencja nowego Sejmu rozpoczynała się po zakończeniu kadencji ustępującej izby $(\$ 26)$. Powyższe przepisy miały na celu zlikwidowanie przerwy międzykadencyjnej ${ }^{57}$.

Na podstawie $\$ 52$ konstytucji prezydent mógł rozwiązać Sejm przed upływem jego kadencji. Nie miał obowiązku podania przyczyny rozwiązania izby ${ }^{58}$, ale mimo to możliwość rozwiązania parlamentu nie była silną bronią w rękach egzekutywy. Przyczyną tego stanu rzeczy było silne uzależnienie Gabinetu Ministrów od Sejmu, przejawiające się w konieczności natychmiastowego złożenia dymisji w razie udzielenia mu wotum nieufności. Jeszcze ważniejszym czynnikiem było obligatoryjne skrócenie kadencji prezydenta, który rozwiązał Sejm. Nowy parlament dokonywał wyboru kolejnego prezydenta. Jak konkludował Michał Römer, „nie zawsze i nie każdy prezydent będzie skłonny do harakiri, którym jest dlań akt rozwiązania Sejmu" ${ }^{\prime 2}$. W związku z tym na akt rozwiązania parlamentu zdecydował się w praktyce tylko A. Stulginskis, gdy uzyskał gwarancję wyboru na kolejną kadencję (zob. niżej, pkt 3.4). W razie rozwiązania Sejmu kolejne wybory musiały się odbyć nie później niż w terminie 60 dni. Kadencja nowego Sejmu rozpoczynała się od dnia wyborów $(\$ 52)^{60}$.

$\mathrm{W}$ świetle $\$ 33$ konstytucji kolegialnym organem kierowniczym Sejmu było Prezydium. Na jego czele stał przewodniczący, do którego zadań należało zwoływanie Sejmu „w porządku przez Sejm ustanowionym”. Sejm obradował na sesjach, przy czym sam ustanawiał czas ich trwania. Musiał zebrać się na sesję nadzwyczajną na żądanie prezydenta lub grupy reprezentującej 1/4 ogółu posłów.

\subsubsection{Funkcje Sejmu}

Podobnie jak w przypadku konstytucji tymczasowych parlament pełnił przede wszystkim funkcję ustrojodawczą, ustawodawczą i kontrolną. W zakresie zmiany konstytucji pozycja Sejmu była relatywnie słabsza niż wynikało by to $\mathrm{z}$ innych przepisów określających jego pozycję ustrojową. Chodzi tu przede wszystkim o możliwość uchylenia zmiany konstytucji uchwalonej przez parlament w drodze referendum. Inicjatywa ustawodawcza w zakresie zmiany konstytucji przysługiwała Sejmowi, Rządowi lub grupie 50000 obywateli (\$ 102). Ustawa musiała być uchwalona większością 3/5 głosów ogólnej liczby posłów (\$103). Zmiana konstytucji wchodziła w życie trzy miesiące po jej ogłoszeniu.

\footnotetext{
${ }^{57}$ A. Hollstein, Das staatsorganisatorische Modell..., s. 40.

${ }^{58}$ P. Kierończyk, Litewskie konstytucje..., s. 249.

${ }^{59}$ M. Römer, Organizacja..., s. 57. P. Kierończyk nazwał rozwiązanie Sejmu przez prezydenta „działaniem cechującym się skrajnym ryzykiem politycznym" (P. Kierończyk, System..., s. 60).

${ }^{60}$ Należy dodać, że konstytucja przewidywała również przedłużenie kadencji przez prezydenta $\mathrm{w}$ razie wybuchu wojny albo wprowadzenia stanu wojennego na co najmniej połowie terytorium kraju. Decyzja prezydenta podlegała zatwierdzeniu przez Sejm (\$25).
} 
Ustawa uchwalona przez Sejm w ciągu trzech miesięcy od jej ogłoszenia (a więc w okresie vacatio legis) na żądanie prezydenta, grupy 50000 wyborców lub 1/4 ogólnej liczby posłów podlegała rozpatrzeniu w drodze referendum. Jeżeli w referendum wzięła udział ponad połowa uprawnionych do głosowania i większość z głosujących opowiedziała się przeciwko zmianie konstytucji, nie wchodziła ona w życie. Referendum nie przeprowadzano, jeżeli Sejm podjął uchwałę o zmianie konstytucji większością 4/5 głosów ogólnej liczby posłów. W takim przypadku uchwała Sejmu wchodziła w dniu ogłoszenia (\$103).

Konstytucja nie regulowała postępowania ustawodawczego, odsyłając do postanowień ustawy, czyli regulaminu Sejmu $(\$ 27)^{61}$. Ograniczała się ona do wskazania podmiotów inicjatywy ustawodawczej. Prawo wniesienia projektu ustawy przysługiwało Gabinetowi Ministrów $(\$ 60)^{62}$ oraz grupie 25000 obywateli $(\$ 20)$. Ponadto regulamin Sejmu przyznawał inicjatywę ustawodawczą również posłom $^{63}$. Ustawę uchwaloną przez Sejm prezydent promulgował w ciągu $21 \mathrm{dni}$, licząc od dnia doręczenia mu ustawy ( $\$ 50$ ust. 1). Prezydent mógł zgłosić weto, które Sejm przełamywał bezwzględną większością głosów ogólnej liczby posłów ( $\$ 50$ ust. 2). Konstytucja umożliwiała zawieszenie uprawnienia prezydenta do złożenia weta w ten sposób, że Sejm większością 2/3 głosów ustawowej liczby posłów mógł uchwalić pilność ustawy ( $\$ 50$ ust. 3 ).

Sejm pełnił funkcję kontrolną, zgłaszając wobec członków rządu zapytania, interpelacje oraz rewizje $(\$ 28)$. Członkowie rządu ponosili przed Sejmem odpowiedzialność solidarną i indywidualną $(\$ 59)$ za działania własne lub za akty prezydenta $(\$ 55)$. Zarówno cały Gabinet Ministrów, jak i każdy minister indywidualnie mógł stać się adresatem wniosku o wotum nieufności (zob. niżej, pkt 3.3.2).

Ponadto Sejm uchwalał budżet państwa i określał sposób jego wykonania $(\$ 29)$ oraz ratyfikował umowy międzynarodowe zawarte przez Rząd, jeżeli dotyczyły spraw określonych $w \$ 30$. Do kompetencji Sejmu należało także wypowiadanie wojny i zawieranie pokoju oraz zatwierdzanie i znoszenie stanów nadzwyczajnych. Niemniej w świetle $\$ 31$ działania wojenne mogły rozpoczać się bez zgody Sejmu, jeżeli inne państwo wypowiedziało wojnę Litwie albo $\mathrm{w}$ razie faktycznego ataku na terytorium Litwy.

${ }^{61}$ Regulamin Sejmu był uchwalany w formie ustawy $(\$ 33)$.

${ }^{62}$ Przepis ten umożliwiał poszczególnym ministrom złożenie votum separatum do projektu ustawy. Zob. krytyczne uwagi M. Römera, którego zdaniem wskutek tego Gabinet Ministrów stawał się tylko „organem pomocniczym Sejmu”, występującym jako „komisja rzeczoznawców”. „Przepis taki nie licuje zgoła z inicjatywą ustawodawczą ciała politycznego rządzącego, jednolitego i solidarnego, które w formie tej inicjatywy realizuje swój program polityczny" (M. Römer, Organizacja..., s. 54).

${ }^{63}$ P. Kierończyk, System..., s. 46; A. Zakrzewski, Wstęp..., s. 14. 


\subsection{Rząd}

W świetle postanowień konstytucji z 1922 r. władzę wykonawczą sprawował Rząd złożony z prezydenta i Gabinetu Ministrów (\$40). Prezydent mógł przewodniczyć posiedzeniom Gabinetu oraz żądać od niego lub poszczególnych ministrów złożenia sprawozdań z ich pracy ( $\$ 54)$. Prezydent, wybierany przez parlament, dysponował niewielkimi kompetencjami, które - zgodnie z regułami systemu parlamentarnego - podlegały kontrasygnacie ${ }^{64}$. Taki model prezydentury był charakterystyczny dla większości ówczesnych konstytucji europejskich ${ }^{65}$.

\subsubsection{Prezydent Republiki}

Tryb wyboru. Prezydenta wybierał Sejm na trzyletnią kadencję, bezwzględną większością głosów, w głosowaniu tajnym. Jeżeli dwa głosowania nie przyniosłyby rezultatu, w trzecim - Sejm wybierał prezydenta spośród dwóch kandydatów, którzy otrzymali największą liczbę głosów. W razie równej liczby głosów za wybranego uważano kandydata starszego wiekiem. Prezydent mógł zostać wybrany ponownie tylko raz na kolejną kadencję. Bierne prawo wyborcze przysługiwało obywatelom litewskim mającym czynne prawo wyborcze w wyborach do Sejmu po ukończeniu 35 roku życia. Warunkiem objęcia mandatu przez prezydenta było złożenie przysięgi ( $\$ 42)$. Prezydent pełnił obowiązki do czasu wybrania następcy $(\$ 44)$. Jedna osoba mogła pełnić urząd prezydenta nie dłużej niż przez dwie kolejne kadencje ( $\$ 44)$, czyli najwyżej przez sześć lat ${ }^{66}$.

W razie wyjazdu prezydenta za granicę, choroby lub czasowej niemożności wypełniania obowiązków głowy państwa, prezydenta zastępował przewodniczący Sejmu ( $\$ 45)$. Jeśli doszło do opróżnienia urzędu, tj. w razie dymisji prezydenta, złożenia go z urzędu, śmierci lub choroby uniemożliwiającej pełnienie obowiązków, Sejm wybierał kolejnego prezydenta na czas, który pozostał jego poprzednikowi do końca kadencji ( $\$ 45$ ust. 2). Przyczyn takiego rozwiązania należy upatrywać w chęci bezwzględnego powiązania kadencji prezydenta z kadencją Sejmu. Dzięki temu każdy Sejm miał „swojego” prezydenta. Był to niewątpliwie czynnik uzależniający głowę państwa od parlamentu ${ }^{67}$.

${ }^{64}$ Pozycja ustrojowa prezydenta była bodaj najbardziej kontrowersyjną kwestią w pracach konstytucyjnych. Za silną prezydenturą opowiadali się początkowo chadecy, powołujący się na przykłady Niemiec, Czechosłowacji i Finlandii. Przeciwne stanowisko reprezentowali socjaldemokraci, którzy - wzorem Estonii - w ogóle chcieli zrezygnować $\mathrm{z}$ instytucji głowy państwa. Jednakże ze względu na sprzeciw pozostałych frakcji zmienili diametralnie swoje stanowisko. Poparli ideę powszechnych i bezpośrednich wyborów prezydenckich. Prezydent wybierany przez naród miał zrównoważyć wpływy chadecji w parlamencie. W odpowiedzi chadecy przesądzili o modelu słabej prezydentury. Zob. P. Łossowski, Kraje battyckie..., s. 24-25.

${ }^{65}$ Zob. W. T. Kulesza, Status głowy państwa w konstytucjach Estonii, Litwy, Łotwy i Polski w międzywojennej Europie, [w:] Wielokulturowość polskiego pogranicza. Ludzie, idee, prawo, red. A. Lityński, P. Fiedorczyk, Białystok 2003, s. 526.

${ }^{66}$ Inaczej podaje P. Kierończyk, którego zdaniem można było objąć urząd prezydenta po raz trzeci, jeżeli po dwóch kadencjach wystąpiła przerwa (P. Kierończyk, System..., s. 48).

${ }^{67}$ M. Römer, Organizacja..., s. 52; por. P. Kierończyk, System..., s. 48. 
Kompetencje. Prezydent w ramach funkcji reprezentanta państwa posiadał prawo czynnej i biernej legacji ( $\$ 46)$. Jak wspomniano wyżej, prezydent dysponował prawem rozwiązania Sejmu, lecz w takiej sytuacji również i jego kadencja się kończyła, a nowy Sejm wybierał kolejnego prezydenta. Prezydent pełnił funkcję najwyższego zwierzchnika sił zbrojnych ( $\$ 53$ ust. 1), ale miała ona charakter symboliczny ${ }^{68}$. Podział kompetencji w sprawach obronności kraju między poszczególne organy państwowe był niejasny ${ }^{69}$. Rolę Sejmu w zakresie nadzoru nad siłami zbrojnymi podkreślał $\$ 53$ ust. 2, według którego Gabinet Ministrów i właściwy minister ponosili parlamentarną odpowiedzialność za organizację i dowództwo nad siłami zbrojnymi. W czasie wojny prezydent powoływał na wniosek Gabinetu Ministrów Naczelnego Wodza ( $\$ 53$ ust. 3).

Prezydent na wniosek Gabinetu Ministrów mógł wprowadzić stan wojenny „lub inny stan wyjątkowy” w razie wybuchu wojny, zbrojnego powstania lub innych niebezpiecznych rozruchów w państwie. W czasie stanu nadzwyczajnego były zawieszane gwarancje konstytucyjnych praw obywatelskich. Prezydent mógł przedsięwziąć również inne środki konieczne dla odwrócenia i odparcia niebezpieczeństwa, w tym podjąć decyzję o użyciu siły zbrojnej. O zastosowanych środkach prezydent powiadamiał Sejm, który zatwierdzał lub uchylał „te kroki rządowe”. Z kontekstu wynika, że Sejm rozpatrywał zarówno samą decyzję o wprowadzeniu stanu wojennego lub stanu wyjątkowego, jak i środki podjęte $\mathrm{w}$ ramach stanu nadzwyczajnego.

Prezydent mianował i odwoływał kontrolera państwowego ( $\$ 48$ ust. 1$)^{70}$ oraz innych urzędników państwowych $(\$ 49)$. Dysponował prawem łaski ( $\$ 51$ ust. 1), z tym że na jego zastosowanie wobec ministrów skazanych za przestępstwo służbowe musiał uzyskać zgodę Sejmu ( $\$ 51$ ust. 2) ${ }^{71}$. Dla swojej ważności akty prezydenta wymagały kontrasygnaty premiera lub odpowiedniego ministra, który przejmował odpowiedzialność za ten akt ( $\$ 55)$.

Odpowiedzialność. Konstytucja Republiki Litewskiej z 1922 r. ustanawiała rzadko spotykaną odpowiedzialność polityczną głowy państwa, niezależnie od odpowiedzialności konstytucyjnej, która również była przewidziana. Na podstawie $\$ 44$ konstytucji Sejm mógł odwołać prezydenta większością 2/3 głosów ogólnej liczby posłów. Konstytucja nie określała przesłanek odwołania prezyden-

${ }^{68}$ P. Kierończyk, Litewskie konstytucje..., s. 249.

${ }^{69}$ Ibidem, s. 252.

${ }^{70}$ Kontroler ponosił odpowiedzialność przed Sejmem. Składał dymisję w razie wyrażenia przez Sejm wotum nieufności ( $\$ 48$ ust. 2). Do zadań kontrolera państwowego należało czuwanie nad dochodami, wydatkami i rachunkowością majątku i długów państwa (\$92), zestawianie corocznego sprawozdania $\mathrm{z}$ wykonania budżetu państwa za poprzedni rok i przedstawianie go Sejmowi do zatwierdzenia w terminie do 15 listopada (\$93).

${ }^{71} \mathrm{~W}$ polskim tłumaczeniu konstytucji błędnie podano: prawo amnestii, co kłóciłoby się z $\$ 65$ ust. 2, w świetle którego amnestię uchwalano w drodze ustawy (tak P. Kierończyk, Litewskie konstytucje..., s. 250, przypis 29). Ponadto należy dodać, że sprawę jednoznacznie przesądza przywołany wyżej $\$ 51$ ust. 2: trudno mówić o amnestii w stosunku do skazanych ministrów. 
ta. Słusznie wskazuje Przemysław Kierończyk, że rozwiązanie to łamało jedną z podstawowych zasad parlamentarno-gabinetowego systemu rządów, zakładającego polityczną neutralizację głowy państwa ${ }^{72}$. Możliwość odwołania prezydenta na podstawie $\$ 44$ konstytucji miała daleko idące konsekwencje ustrojowe, zwłaszcza że - jak wskazano wyżej - Sejm obligatoryjnie wybierał nowego prezydenta w razie rozwiązania izby. Zdaniem M. Römera, „,usuwalność Prezydenta Republiki z mocy uchwały Sejmu, który Prezydenta wybiera, czyni mandat Prezydenta nie reprezentacyjnym, lecz imperatywnym"73. Najlepszym przykładem na potwierdzenie tej tezy było jedyne w praktyce rozwiązanie Sejmu, którego prezydent A. Stulginskis dokonał na życzenie „swojej” partii (chrześcijańskiej demokracji) w marcu 1923 r. (zob. niżej, pkt 3.4). Ewentualna odmowa mogła skutkować odwołaniem prezydenta przez większość sejmową.

Możliwość odwołania prezydenta zawierała również konstytucja Łotwy (art. LI). Rozwiązanie to - funkcjonujące zresztą na Łotwie po dzień dzisiejszy - było tym bardziej osobliwe, że konstytucja ustanawiała expressis verbis nieponoszenie przez prezydenta odpowiedzialności politycznej. Konstytucja litewska nie zawierała takiego przepisu, niemniej - jak wspomniano wyżej - wprowadzała kontrasygnatę aktów urzędowych prezydenta i przejęcie przez ministrów odpowiedzialności politycznej za działania prezydenta ${ }^{74}$.

Prezydent ponosił odpowiedzialność konstytucyjną za przestępstwo służbowe lub zdradę stanu. Sejm podejmował w tej sprawie uchwałę bezwzględną większością głosów ogólnej liczby posłów. O odpowiedzialności prezydenta orzekał Sąd Najwyższy (\$63). Na takiej samej zasadzie jak prezydent odpowiedzialność konstytucyjną ponosili członkowie Gabinetu Ministrów (\$68).

\subsubsection{Gabinet Ministrów}

Gabinet Ministrów składał się z premiera i ministrów ( $\$ 56$ ust. 1). Liczbę ministrów oraz zakres ich kompetencji określał Sejm w drodze ustawy ( $\$ 56$ ust. $2)^{75}$. Prezydent miał prawo udziału w posiedzeniach Gabinetu Ministrów i przewodniczenia obradom $(\$ 54)$. W posiedzeniach Rady Ministrów mógł uczestniczyć z głosem doradczym kontroler państwowy (\$ 62). Zadania Gabinetu Ministrów określała konstytucja $\mathrm{w} \$ 61$. Należało do nich wykonywanie konstytucji i ustaw, prowadzenie polityki wewnętrznej i zagranicznej oraz stanie na straży nienaruszalności terytorium państwa i ładu wewnętrznego.

${ }^{72}$ P. Kierończyk, System..., s. 48-49.

${ }^{73}$ M. Römer, Organizacja..., s. 53.

${ }^{74}$ Możliwość odwołania prezydenta z urzędu znalazła się również w konstytucji weimarskiej, a od 1929 r. w konstytucji austriackiej; zob. K. Dunaj, O specyficznych postaciach politycznej odpowiedzialności prezydenta, [w:] Z zagadnień współczesnych społeczeństw demokratycznych, red. A. Jamróz, S. Bożyk, Białystok 2006, s. 203-204.

${ }^{75}$ Był to jeden z wielu przejawów uzależniających Gabinet Ministrów od parlamentu; zob. A. Hollstein, Das staatsorganisatorische Modell..., s. 41. 
Inicjatywa powołania Gabinetu Ministrów spoczywała w rękach prezydenta, który wyznaczał Prezesa Ministrów (Ministros Piriminikas) i polecał mu utworzenie Gabinetu Ministrów, a następnie zatwierdzał jego skład ( $\$ 47$, por. $₫ 57$ ust. 1$)^{76}$. Kompetencja prezydenta do powołania premiera i powierzenia mu misji utworzenia rządu miała charakter formalny ${ }^{77}$. Swoboda premiera w doborze ministrów swojego rządu była bowiem ograniczona układem politycznym w parlamencie ${ }^{78}$. W świetle $₫ 59$ wotum zaufania musiało być udzielone wprost: „Ministrowie winni posiadać zaufanie Sejmu”. Nie można więc było ograniczyć się tylko do domniemania wotum zaufania ${ }^{79}$.

Gabinet ponosił solidarną odpowiedzialność za prowadzoną przez siebie politykę. Ponadto każdy minister ponosił odpowiedzialność indywidualną „za swoją działalność w powierzonej mu dziedzinie administracji” ( $\$ 59)$. Z przepisu $\$ 59$ w związku z $\$ 56$ ust. 1, w świetle którego Gabinet Ministrów tworzyli Prezes Ministrów i „inni ministrowie”, należy wnioskować, że ministrem, któremu w myśl $\$ 59$ Sejm mógł uchwalić wotum nieufności, był także sam premier. Wniosek taki wypływa również z innych przepisów konstytucyjnych, określających pozycję premiera na zasadzie primus inter pares.

Sejm uchwalał wotum nieufności zwykłą większością głosów ${ }^{80}$. Konstytucja nakazywała Gabinetowi (jak i ministrowi) natychmiastowe złożenie dymisji, jeżeli tylko Sejm bezpośrednio wyraził mu wotum nieufności. Nie działał tutaj mechanizm wyborów jako czynnika rozstrzygającego kryzys gabinetowy ${ }^{81}$. Prezydent przyjmował dymisję Gabinetu Ministrów ( $\$ 47)$ i poszczególnych ministrów ( $\$ 57$ ust. 2). Z uwagi na konstytucyjne relacje między parlamentem a głową państwa, należy sądzić, że prezydent nie mógł odmówić przyjęcia dymisji Gabinetu lub ministra, któremu Sejm udzielił wotum nieufności.

Jedynym elementem osłabiającym dominującą pozycję Sejmu był przepis nakazujący, by wotum nieufności było udzielone Gabinetowi Ministrów „wprost”. Dopóki więc wotum nieufności nie zostało udzielone, mimo zaistniałego kryzysu rządowego, Gabinet (lub minister) nie miał obowiązku złożenia dymisji. Co więcej, egzekutywa mogła doprowadzić (przynajmniej teoretycznie) do rozwiązania Sejmu.

${ }^{76}$ Przez „zatwierdzenie” składu Gabinetu Ministrów należy rozumieć akt jego powołania (P. Kierończyk, System..., s. 50, przypis 110).

${ }^{77}$ A. Hollstein, Das staatsorganisatorische Modell..., s. 42; podobnie P. Kierończyk, System..., s. 50-51 , przypis 110.

${ }^{78}$ Zob. M. Römer, Organizacja..., s. 54.

${ }^{79}$ Taka możliwość występowała w konstytucji Republiki Weimarskiej (art. 54).

${ }^{80} \mathrm{~J}$. Zieliński, Instytucjonalizacja..., op. cit., s. 26, przypis 40.

${ }^{81}$ „Sejm jest tutaj w stosunku do rządu nie stroną, lecz panem, rząd zaś (Gabinet Ministrów) agentem Sejmu” (M. Römer, Organizacja..., s. 55). 


\subsection{3. $S a ̨ d^{82}$}

Zważywszy na stosunkowo obszerną regulację organów władzy ustawodawczej i wykonawczej, dość skromnie wyglądają przepisy w konstytucji z 1922 r. traktujące o władzy sądowniczej. Był to i tak znaczny postęp we stosunku do konstytucji tymczasowych, które w ogóle nie zajmowały się problematyką „trzeciej władzy" (zob. wyżej, pkt 2.2). Kluczowym przepisem określającym pozycję ustrojową władzy sądowniczej był $\$ 2$ konstytucji, który wymieniał sąd jako organ sprawujący władzę państwową. Bardziej szczegółowo władzę sądowniczą regulowały przepisy rozdziału V konstytucji. W świetle $\$ 64$ sąd wydawał wyroki w imieniu Republiki, na podstawie obowiązujących ustaw. Orzeczeń sądu nie mogły zmienić inne organy władzy państwowej, jak tylko sąd według procedury określonej przez ustawę ( $\$ 65$ ust. 1 ). Wyjątkiem od tej zasady była amnestia, którą mógł uchwalić Sejm w drodze ustawy (\$ 65 ust. 2). Wyżej była mowa o prezydenckim prawie łaski.

Organizację, właściwość i jurysdykcję sądów określała ustawa ( $\$ 66) . \mathrm{Na}$ czele hierarchii sądów powszechnych stał Sąd Najwyższy ${ }^{83}$ (Auksciausiasis Lietuvos Teismas), obejmujący swoją jurysdykcją obszar całego kraju (\$67). Oprócz sądów powszechnych konstytucja przewidywała powołanie sądów specjalnych, które były właściwe dla sądzenia przestępstw popełnionych przez wojskowych ( $\$ 69$ ust. 1). Sądy nadzwyczajne mogły być ustanowione tylko w czasie wojny lub stanu wyjątkowego ( $\$ 69$ ust. 2). Należy również dodać, że konstytucja przewidywała sądową kontrolę administracji (\$ 68).

\subsection{Praktyka ustrojowa pod rządami konstytucji z 1922 r.}

Na praktykę ustrojową pod rządami konstytucji z 1922 r. wpłynęły dwa podstawowe czynniki: dominacja partii chadeckiej na scenie politycznej oraz utrzymujący się stan nadzwyczajny. W wyborach do Sejmu I kadencji (10-11 października 1922 r.) chrześcijańska demokracja zdobyła tylko 38 mandatów, a więc nie utrzymała większości bezwzględnej, którą miała w Sejmie Ustawodawczym. Z drugiej strony opozycja nie była w stanie utworzyć alternatywnej koalicji rządowej. E. Galvanauskas ponownie otrzymał misję utworzenia rządu, ale w głosowaniu nad wotum zaufania padł wynik remisowy. Rząd poparło 38 posłów, tyle samo było przeciw. Mimo to chadecja uważała, że rząd otrzymał wotum zaufania. Dzięki temu gabinet E. Galvanauskasa utrzymał się do marca $1923 \mathrm{rr}^{84}$ Podobne kontrowersje towarzyszyły wyborowi A. Stulginskisa na urząd prezydenta. Były one spowodowane nieprecyzyjnymi przepisami konstytucji. W świetle $₫ 41$ Sejm wybierał prezydenta bezwzględną większością głosów. Kon-

${ }^{82}$ Konstytucja posługiwała się terminem „sąd” w liczbie pojedynczej. Nie używała natomiast pojęcia „władza sądownicza” czy też „sądy”.

${ }^{83}$ Tak w polskim tłumaczeniu konstytucji; z innych źródeł wynika, że lepsza była nazwa: Najwyższy Trybunał Litewski.

${ }^{84}$ P. Łossowski, Litwa..., s. 101. 
stytucja nie precyzowała, czy chodzi o większość bezwzględną głosów posłów biorących udział w głosowaniu (w praktyce taką większością został wybrany A. Stulginskis), czy o większość bezwzględną ogólnej liczby posłów ${ }^{85}$. W związku z tymi kontrowersjami opozycja utrzymywała, że chadecja nie ma legitymacji do sprawowania władzy.

Chadecy postanowili rozwiązać kryzys polityczny w drodze przyspieszonych wyborów parlamentarnych. Prezydent A. Stulginskis - dyspozycyjny wobec oczekiwań kierownictwa swojej partii - na jego żądanie rozwiązał Sejm 13 marca $1923 \mathrm{r} .{ }^{86}$ Plan chadeków w pełni się powiódł, gdyż w przyspieszonych wyborach 12-13 maja 1923 r. zdobyli 40 mandatów i odzyskali większość parlamentarną. W czerwcu Sejm wybrał na drugą kadencję prezydenta A. Stulginskisa i powołał rząd E. Galvanauskasa ${ }^{87}$. Rok później, 18 czerwca 1924 r. zastąpił go gabinet Antanasa Tuménasa ${ }^{88}$.

Chadecja rządziła w sposób arbitralny, zwalczając wszelką opozycję. Służyły temu restrykcyjne przepisy stanu wojennego, umożliwiające ograniczenie swobód obywatelskich i przekazanie władzy w ręce komendantów wojskowych ${ }^{89}$. Utrudniano działalność partii politycznych, z wyjątkiem rządzącej chadecji. Obowiązywanie stanu wojennego w warunkach pokoju wzbudzało coraz szerszą krytykę, ale była ona możliwa tylko z trybuny sejmowej. Przez dwa lata chadecja nie dopuściła do głosowania nad wnioskiem o zniesienie stanu wojennego ${ }^{90}$.

Niepopularność rządów partii chadeckiej, spowodowana głównie utrzymującym się reżimem stanu wojennego, doprowadziły do jej porażki w wyborach do Sejmu III kadencji, które odbyły się 8-10 maja 1926 r. Chadecja zdobyła tylko 30 mandatów, sukces zaś odniosły partie opozycyjne. Ludowcy zdobyli 22 mandaty, a socjaldemokraci $15^{91}$. Na nowego prezydenta wybrano K. Griniusa. Początkowo ludowcy chcieli zawrzeć koalicję rządową $\mathrm{z}$ chadekami, ale ostatecznie zdecydowali się na sojusz z socjaldemokracjąą ${ }^{92}$ Koalicja dysponowała tylko 37 mandatami, w związku z czym trzeba było zabiegać dodatkowo o poparcie u mniejszości narodowych. Gabinet M. Slezevičiusa zniósł stan wojenny i przeprowadził szereg reform ${ }^{93}$. Jego upadek, a jednocześnie faktyczny

${ }^{85}$ P. Kierończyk, Państwo..., s. 84, przypis 18.

${ }^{86}$ Trudno nie zgodzić się z M. Römerem, że „było to więc w istocie rozwiązanie się przez Sejm, dokonane w formie aktu Prezydenta Republiki” (M. Römer, Organizacja..., s. 56-57).

${ }^{87}$ P. Łossowski, Litwa..., s. 103.

${ }^{88}$ J. Zieliński, Rząd..., s. 123.

${ }^{89}$ Dowódcy wojskowi regulowali drobiazgowo sprawy życia społecznego. Nie tylko reglamentowali działalność partyjną i związkową, wolność prasy i zgromadzeń, ale także np. wspólne zażywanie kąpieli w rzekach przez kobiety i mężczyzn (P. Łossowski, Kraje bałtyckie..., s. 47).

${ }^{90}$ Ibidem, s. 48.

${ }^{91}$ Ponadto mandaty zdobyli przedstawiciele mniejszości narodowych, narodowcy i Partia Rolników; zob. D. Świgliński, Litwa..., s. 206-207.

${ }^{92}$ P. Łossowski, Kraje bałtyckie..., s. 83.

${ }^{93}$ Ibidem, s. 84-89. 
koniec funkcjonowania konstytucji z 1922 r.94, wiąże się zamachem grudniowym 1926 r., za którym stali odsunięci od władzy chadecy i dysponujący wpływami w siłach zbrojnych narodowcy.

\section{Podsumowanie}

Konstytucje litewskie, uchwalone w pierwszych latach po uzyskaniu niepodległości, przyjmowały popularny w ówczesnej Europie model przewagi parlamentu w systemie organów państwowych. Wzorzec ustanowiony w pierwszej tymczasowej konstytucji z 2 listopada $1918 \mathrm{r}$. został przyjęty przez kolejne ustawy zasadnicze i Konstytucję Republiki Litewskiej z 1922 r. Głowa państwa (najpierw Prezydium Taryby, później prezydent) z reguły pełniła tylko funkcje reprezentacyjne. Najsilniejszą pozycję miał niewątpliwie prezydent A. Smetona (1919-1920), który realizował w praktyce konstytucyjne uprawnienie do wydawania ustaw w zastępstwie parlamentu. Po wyborach do Sejmu Ustawodawczego (1920) pozycja prezydenta znacznie osłabła. Przez wiele lat funkcję głowy państwa pełnił A. Stulginskis, najpierw jako przewodniczący Sejmu Ustawodawczego, a po uchwaleniu konstytucji z 1922 r. już jako Prezydent Republiki. Był on całkowicie uzależniony od swojego zaplecza politycznego (Partii Chrześcijańsko-Demokratycznej), o czym najlepiej świadczą okoliczności rozwiązania Sejmu w 1923 r. Od samego początku w Republice Litewskiej funkcjonował parlamentarny system rządów. Gabinet Ministrów, powoływany przez głowę państwa, musiał cieszyć się zaufaniem parlamentu i ponosił przed nim solidarną odpowiedzialność.

System rządów Republiki Litewskiej w okresie obowiązywania konstytucji z 1922 r. nie poddaje się jednoznacznej klasyfikacji. Zasadniczo był on oparty na rozwiązaniach charakteryzujących system parlamentarno-gabinetowy. Poważnym wyłomem była jednak polityczna odpowiedzialność prezydenta przed Sejmem. Konstytucja nie gwarantowała więc politycznej neutralizacji głowy państwa. Pozycję prezydenta osłabiało również powiązanie jego kadencji z kadencją Sejmu. P. Kierończyk określa ten system rządów jako zracjonalizowany system parlamentarno-gabinetowy, przy czym racjonalizacja ta biegła w kierunku osłabienia pozycji prezydenta ${ }^{95}$.

Najpełniej literę i ducha konstytucji realizowano w drugiej połowie 1926 r., w okresie rządów M. Slezevičiusa. Było to apogeum funkcjonowania systemu demokratycznego w międzywojennej Republice Litewskiej ${ }^{96}$. Po zamachu stanu w grudniu 1926 r. urząd prezydenta objął ponownie A. Smetona, który rządził

${ }^{94}$ Formalnie rzecz biorąc konstytucja z 1922 r. obowiązywała aż do wejścia w życie kolejnej konstytucji z $1928 \mathrm{r}$.

${ }^{95}$ P. Kierończyk, Państwo..., s. 83; por. J. Stembrowicz, Rzad..., s. 85.

${ }^{96}$ P. Kierończyk, Państwo..., s. 84. 
przez wiele lat bez obecności parlamentu. W 1928 r. oktrojował nową konstytucję, która pod względem literalnego brzmienia nie wprowadzała wiele zasadniczych zmian, ale sankcjonowała dokonany zamach stanu. Dziesięć lat później Litwa doczekała się kolejnej konstytucji, która wprowadzała system rządów zbliżony do polskiej Konstytucji kwietniowej. Kres pierwszej Republiki Litewskiej wiązał się - jak wiadomo - $\mathrm{z}$ wybuchem II wojny światowej i wcieleniem do ZSRR, co ostatecznie nastąpiło w 1944 r. po wyparciu przez Armię Czerwoną wojsk Niemiec hitlerowskich. 